\title{
Tartalmi feltárás az ELTE könyvtári hálózatában
}

\section{Örökség és hagyományok}

Az Eötvös Loránd Tudományegyetem (a továbbiakban: ELTE) könyvtári hálózatát a 2000-es évekig a széttagoltság jellemezte. A kollégiumi, tanszéki, intézeti és kari könyvtárakban, valamint az Egyetemi Könyvtárban különbözö mértékü tematikai átfedésekkel jellemezhetö állomány, változatos dokumentumtípusok és többféle feltárási módszer volt jelen, valamint az oktatóknak és hallgatóknak nyújtott szolgáltatások is különböztek. A közös fenntartó, az egyetem mindenkori céljait szolgáló könyvtárszakmai munkák irányítása és végrehajtása is jellemzően külön-külön, legfeljebb kari szinten összefogva folyt. Nagyjából 2000-töl kezdődően azonban mind a külső, mind a belső körülmények változásokat indukáltak. A mai intézményi - és ebből következően könyvtári - struktúra kialakulásához nagy lépést jelentett 2000-ben két főiskola integrációja, a Budapesti Tanítóképző Főiskola Tanító- és Óvóképző Karként, valamint a Bárczi Gusztáv Gyógypedagógiai Tanárképző Főiskola Bárczi Gusztáv Gyógypedagógiai Karként csatlakozása. Rá három évre intézményi önállósulással megalakult az Informatikai, a Pedagógiai és Pszichológiai, valamint a Társadalomtudományi Kar, mind-mind önálló könyvtárral. Ezen öt szervezeti egység mindegyike rendelkezett saját könyvtárral.

Az egyetemi könyvtári rendszer 2000-es évekre jellemző széttagoltsága a munkafolyamatok széles spektrumára volt hatással, köztük a formai és tartalmi feldolgozásra is. Eltérő gyakorlatok (a szabványos és szabályos formák mellett nem ritkán évtizedes „hagyományok”) uralkodásán kívül a feldolgozás módszere is változatos volt: volt, ahol még papíron, volt, ahol számítógépes nyilvántartásokban, táblázatokban, és volt, ahol saját fejlesztésủ adatbázisokban vagy már különböző integrált könyvtári rendszerekben dolgoztak. Ezek a helyben átlátható és - következetes munkavégzés esetén - az adott szervezeti egységben elszigetelten, de múködőképes rendszert alkotó metódusok azonban az egyetemi szinten közös és egységes dokumentumfeltárás, továbbá a feldolgozási párhuzamosságok kiküszöbölése érdekében fejlesztésre és módosításokra szorultak.

Az ELTE könyvtárainak szervezettségében nagy változást hozott az Egyetemi Könyvtári Szolgálat (EKSz) 2009-es megalakulása. ${ }^{1}$ Ezt követően kezdőd-

${ }^{1}$ L. XXXIV/2009. (III. 23.) Szen. sz. határozat az Egyetemi Könyvtár hálózati reform koncepciójának elfogadásáról. https://www.elte.hu/file/szen090323_1m.pdf (2019. november 17.) 
hetett el az egységes egyetemi könyvtári hálózat kialakítása, melynek minden, az egyetemen lévő könyvtár a tagja: az Egyetemi Könyvtár és a kari, intézeti, tanszéki könyvtárak mellett a kari szervezetbe nem tartozó (pl. kollégiumi, középiskolai) gyüjtemények is. Központi koordinációs feladatokat a Könyvtári Tanács látott, és lát el mind a mai napig: sok más feladatkör mellett a szakmai irányítást, a dokumentumfeldolgozás és szolgáltatások egységesítését és a gyüjtőkör egyeztetését is.

Az egyetemi szinten egységes formai és tartalmi feltárás megszületéséhez a másik kardinális feltétel az egységes integrált könyvtári rendszer használata volt. Az ELTE 2010-ben vásárolta meg, és 2011 elején vezette be az Aleph-et, ${ }^{2}$ majd indult el ezzel egyidőben a korábbi rendszerek migrálása:

1. 2011 januárjában a Horizon (Egyetemi Könyvtár és több kar),

2. 2011 szeptemberében az SRLib (PPK),

3. szintén 2011 szeptemberében a Corvina (BGGYK),

4. és azóta is folyamatosan további intézeti, tanszéki állományok változatos, kisebb adatbázisokból, számítógépes nyilvántartásokból.

Az egyetemi dokumentumállomány áttekinthetővé válása, valamint a közös kereső vitathatatlan haszna mellett azonban a különböző rendszerek egy adatbázisba kerülése a korábbinál látványosabb módon irányította rá a figyelmet a különbségekre. Az adatbázisok migrálásakor rengeteg egységesítés és javítás központilag, számítógéppel készült el (például duplumkezelések, HUNMARC-MARC21 megfeleltetések), de a géppel nem megfogható, sokszor eltérö formai és tartalmi feldolgozói szabályok követéséből, továbbá elsősorban a tartalmi feltárás különböző szóhasználatából és mélységéből fakadó különbségeket csak emberi közreműködéssel lehetett kezelni. Emiatt a közös integrált könyvtári rendszerbe töltést követően sok szervezeti egységnél a nem csekély humánerőforrást igénylő kézi javításra volt - és néhány esetben van mind a mai napig - szükség. ${ }^{3}$

A gépi és manuális javítások mellett szükségessé vált a közös formai és tartalmi feldolgozói módszerek összehangolása, mindkét területen egy-egy egységes, az országos szabványokra és a korszerü tendenciákra épülő szabályzat

${ }^{2}$ A témáról bővebben 1.: Áts József - Czinki-Vietorisz Gabriella - Székelyné Török Tünde: Aleph integrált könyvtári rendszer az ELTE könyvtáraiban. = Könyv, Könyvtár, Könyvtáros, 25. évf. 2016. 7. sz. 11-21. p. http://ki2.oszk.hu/3k/2016/07/aleph-integralt-konyvtari-rendszer-azelte-konyvtaraiban (2020. július 15.)

${ }^{3}$ Az elvégzett munkákról, szakmai kihívásokról 1.: Boda Gáborné Köntös Nelli - Székelyné Török Tünde: Szabványos bibliográfiai rekordok a minőségi szolgáltatás érdekében: a közös katalógusépítés tapasztalatai az ELTE könyvtáraiban. = Könyvtári Figyelö, 62. évf. 2016. 2. sz. 185192. p.; Székelyné Török Tünde: A katalóguscédulától a szemantikus webig: közös elektronikus katalógus építése az ELTE könyvtáraiban. = Tudományos és Müszaki Tájékoztatás, 66. évf. 2019. 5. sz. 273-286. p. https://tmt.omikk.bme.hu/tmt/article/view/12092/13731 (2020. szeptember 16.) 
bevezetése, majd betartatása. Egyúttal kezelni kellett az eltérő felhasználói igényekből fakadó különbségeket is: a tartalmi feltárás területén ugyanazt a kiadványt egészen más szempontból és szóhasználattal kereshetik a rokon szakterületek oktatói vagy hallgatói (például a három pedagógiai kar esetében pszichológiai, neveléstudományi, vagy éppen gyógypedagógiai hangsúlyból).

A Könyvtári Tanács a szakmai munkák koordinálására 2012-ben több munkabizottságot hozott létre. E bizottságok tagjai a szakterület gyakorló képviselőiből kerültek ki, és elvárás szerint az Egyetemi Könyvtár és minden kar delegált egy-egy képviselőt, illetve tervben volt a karon kívüli könyvtárak képviselete is. Az Integrált Könyvtári Rendszer Munkabizottság (IKR MB, majd később Koordinációs Bizottság: IKR KB) feladatai közé tartozott az adatbázis egységes alakítása, a javítási folyamatok stratégiájának közös kidolgozása, a munka szervezése, a határidők meghatározása és betartatása, az integrált könyvtári rendszer tartalmának minőségi nyomon követése, a duplumösszevonások koordinálása, a fejlesztési irányok megfogalmazása (például az ürlapok egységesítése), és az úgynevezett korrektezés (a tárgyszóláncok átalakítása másik formára) sorrendjének meghatározása, valamint a végzésének összehangolása. A feladatok sokfélesége és a problémák összetettsége miatt, a hatékonyabb munkavégzés érdekében az IKR Munkabizottságon belül öt almunkabizottság kezdte meg müködését: a formai feldolgozásért, a tartalmi feldolgozásért, a folyóirat-kezelésért, a kölcsönzésért és a WebOPAC-ért felelős csoport.

\section{A Tartalmi Feldolgozás Almunkabizottság}

Az Egyetemi Könyvtári Szolgálaton, illetve az Integrált Könyvtári Rendszer Munkabizottságon belül a Tartalmi Feldolgozás Almunkabizottság (a továbbiakban: TAMB) kapta feladatul az osztályozással, tartalmi feltárással kapcsolatos kérdéskörök egyetemi szintü koordinációját és rendezését, az egységes munkavégzés feltételeinek megteremtését. Az almunkabizottság vezetője Aszalós Károly lett, az Egyetemi Könyvtár több mint három évtizedes szakozói gyakorlattal rendelkező munkatársa. A TAMB munkájában a 2012-2019 közötti időszakban közremüködőket és képviseleti idejüket az 1. táblázat sorolja fel.

\begin{tabular}{|l|l|c|c|c|c|c|c|c|c|}
\hline \multicolumn{1}{|c|}{ Név } & \multicolumn{1}{|c|}{$\begin{array}{c}\text { Szervezeti } \\
\text { egység }\end{array}$} & 2012 & 2013 & 2014 & 2015 & 2016 & 2017 & 2018 & 2019 \\
\hline $\begin{array}{l}\text { Aszalós Károly } \\
\text { (vez.) }\end{array}$ & $\begin{array}{l}\text { Egyetemi } \\
\text { Könyytár }\end{array}$ & $\mathrm{x}$ & $\mathrm{x}$ & $\mathrm{x}$ & $\mathrm{x}$ & $\mathrm{x}$ & $\mathrm{x}$ & $\mathrm{x}$ & \\
\hline $\begin{array}{l}\text { Szabó Panna } \\
\text { (vez.) }\end{array}$ & $\begin{array}{l}\text { Egyetemi } \\
\text { Könyvtár }\end{array}$ & & & & & & & $\mathrm{x}$ & $\mathrm{x}$ \\
\hline Kiss Edina & ELTE ÁJK & $\mathrm{x}$ & $\mathrm{x}$ & $\mathrm{x}$ & $\mathrm{x}$ & $\mathrm{x}$ & $\mathrm{x}$ & $\mathrm{x}$ & $\mathrm{x}$ \\
\hline
\end{tabular}




\begin{tabular}{|l|l|c|c|c|c|c|c|c|c|}
\hline Sot Ferenc & ELTE BGGYK & $\mathrm{x}$ & $\mathrm{x}$ & $\mathrm{x}$ & $\mathrm{x}$ & $\mathrm{x}$ & $\mathrm{x}$ & $\mathrm{x}$ & $\mathrm{x}$ \\
\hline $\begin{array}{l}\text { Dubniczky } \\
\text { Zsolt }\end{array}$ & ELTE BTK & $\mathrm{x}$ & $\mathrm{x}$ & $\mathrm{x}$ & $\mathrm{x}$ & $\mathrm{x}$ & $\mathrm{x}$ & $\mathrm{x}$ & $\mathrm{x}$ \\
\hline $\begin{array}{l}\text { a TTK } \\
\text { képviselóje }\end{array}$ & ELTE IK & $\mathrm{x}$ & $\mathrm{x}$ & & & & & & \\
\hline Dancs Ágnes & ELTE IK & & & $\mathrm{x}$ & $\mathrm{x}$ & & & & \\
\hline $\begin{array}{l}\text { Németh } \\
\text { Gabriella }\end{array}$ & ELTE IK & & & & & $\mathrm{x}$ & & & \\
\hline Szabó Tibor & ELTE IK & & & & & & $\mathrm{x}$ & $\mathrm{x}$ & $\mathrm{x}$ \\
\hline Sánta Erzsébet & ELTE PPK & $\mathrm{x}$ & $\mathrm{x}$ & $\mathrm{x}$ & & & & & \\
\hline $\begin{array}{l}\text { Rozniakowsk- } \\
\text { Wéber } \\
\text { Elzbieta }\end{array}$ & ELTE PPK & & & & & & & & \\
\hline $\begin{array}{l}\text { Kakasyné } \\
\text { Endrei } \\
\text { Magdolna }\end{array}$ & ELTE TÁTK & $\mathrm{x}$ & $\mathrm{x}$ & $\mathrm{x}$ & $\mathrm{x}$ & & & $\mathrm{x}$ & $\mathrm{x}$ \\
\hline $\begin{array}{l}\text { Tilhof } \\
\text { Alexandra }\end{array}$ & ELTE TÁTK & & & & & $\mathrm{x}$ & $\mathrm{x}$ & $\mathrm{x}$ & $\mathrm{x}$ \\
\hline Réder Krisztina & ELTE TÓK & $\mathrm{x}$ & $\mathrm{x}$ & $\mathrm{x}$ & $\mathrm{x}$ & $\mathrm{x}$ & $\mathrm{x}$ & $\mathrm{x}$ & $\mathrm{x}$ \\
\hline Erdei Irma & ELTE TTK & $\mathrm{x}$ & $\mathrm{x}$ & & & & & & \\
\hline Zalka Dóra & ELTE TTK & & & $\mathrm{x}$ & & & & & \\
\hline Csámer Iván & ELTE TTK & & & & $\mathrm{x}$ & & & & \\
\hline Szabó Noémi & ELTE TTK & & & & $\mathrm{x}$ & $\mathrm{x}$ & & & $\mathrm{x}$ \\
\hline Rihmer Aurél & ELTE TTK & & & & & & $\mathrm{x}$ & & \\
\hline Földes Szilvia & ELTE TTK & & & & & & & $\mathrm{x}$ & \\
\hline nincs & Känyvtárak & & & & & & & & \\
\hline
\end{tabular}

1. táblázat. A TAMB tagjai 2012-2019 között

A bizottság 2012-es megalakulása után elsőként megalkotta saját müködési rendjét és munkatervét. A munkát a rendszeres ülések és élénk kommunikáció jellemezte, melynek keretében a következő főbb problémákat fogalmazták meg: 1. nincs szabvány; 2. többféle feltárási szabályzat él az egyetemen belül is; 3 . a szabadszavas tárgyszavazás mellett csak néhány könyvtár alkalmaz nem természetes nyelvi feltárást, az Egyetemes Tizedes Osztályozást (ETO-t); 4. a tárgyszóláncos feldolgozás mellett különálló tárgyszavakat, kulcsszavakat alkalmazó könyvtárak is vannak. A munkálatok elején meghatározták a haladási irányt: az egységes 
tartalmi feltárás érdekében szabályzatot, fogalomtárt és szinonimalistát készítenek, melyek használata minden EKSz-tagkönyvtárban kötelező lesz. Egy szavazás keretében döntöttek a tárgyszavazási módról is, a tárgyszóláncos megoldás mellett téve le a voksot. A prioritások meghatározása után, Czinki-Vietorisz Gabriella összeállítása ${ }^{4}$ alapján, 2017-ig a következö főbb feladatok készültek el:

- Definiálták a javítási, szerkesztési jogosultságokat.

- Kidolgozták az EKSZ egészében alkalmazandó egységes tárgyszavazási gyakorlatot, amivel javították a tematikus keresés minőségét az adatbázisban.

- EKSZ-szinten a következő szabályzatokat fogadták el:
$\square$ Filozófia
$\square$ Mủvészetek
$\square$ Pedagógia
$\square$ Politika
$\square$ Pszichológia
$\square$ Természettudományok I.
$\square$ Történelem
$\square$ Vallás

- A Tartalmi Feldolgozás Almunkabizottság által elfogadott, de még kiküldésre, egyeztetésre váró szabályzatok:

$\square$ Egyéb szabályok

$\square$ Földrajz + kiegészítésekkel

$\square$ Kronológia (kiegészítés)

$\square$ Latin és görög irodalom terminológiája

$\square$ Orvostudomány

$\square$ Természettudományok II.

- Kidolgozás alatt lévő szabályzatok:

$\square$ Jogtudomány

$\square$ Társadalomtudományok

$\square$ Testületi tárgyi melléktételek

- Az almunkabizottság elkezdte a szabályzatok egybeszerkesztését.

- Mindezzel párhuzamosan készültek a mellékletek is:

$\square$ A szinonimalistába 2017-ig 113 tételt vettek fel, és 207 tétel egyeztetése volt folyamatban.

$\square$ A fogalomtárba több mint 30 tételt vettek fel, nagy részét ki is dolgozták.

${ }^{4}$ Czinki-Vietorisz Gabriella: IKR almunkabizottságok mủködése az Egyetemi Könyvtári Szolgálatban. = Az Egyetemi Könyvtár Évkönyvei, 2018. 17. sz. 7-20. p. DOI: https://doi.org/ 10.21862/EKevkony.17.2018.7 
A példatár szerkesztés alatt állt, a kiküldését a teljes szabályzat elkészülte utánra tervezték.

- Az elfogadott szabályzatrészekkel összhangban elkezdték a tárgyszóláncok javítását. Jelentősebb előrehaladást az irodalmi, történelmi, gyógypedagógiai, vallási tárgyszavaknál, valamint a szótáraknál értek el. Emellett folyamatosan, a duplumszüréssel párhuzamosan rekordonként is javították a tárgyszóláncokat.

A 2018-2019 közötti időszakban e megkezdett munkák folytatása, részben teljessé tétele folyt. Elkészült, majd jóváhagyásra és bevezetésre került a szabályzat összes szakterületi fejezete, valamint bővült a szinonimalista és a fogalomtár is. A napi feladatok mellett kisebb kapacitással ugyan, de a tárgyszóláncok javítása, úgynevezett korrektezése is zajlott, és az EKSz tagkönyvtáraiban a tartalmi feltárás is egyre több helyen vált szabálykövetővé. Mielőtt azonban rátérnénk az egyre nyilvánvalóbbá váló problémákra és korlátokra, nézzük meg, milyen módszerek szerint kell a dokumentumok tartalmi feltárását elvégezni az egyetemen!

\section{Szabályok és módszerek}

Az előkészítő munkálatok után az ELTE EKSZ tartalmi feltárás (tárgyszavazás) szabályzata $^{5}$ címü dokumentumot 2015-ben fogadta el a Könyvtári Tanács, és lépett életbe. Saját meghatározásában a következőképpen pozícionálja magát: „[...] a tárgyszavazás legfontosabb szabályait foglalja össze, nem tér ki minden lehetséges megoldásra. A szabályzat egyes pontjai részben ajánlások, melyektől a dokumentum tartalmának megfelelően el lehet térni. A sémák nem tartalmaznak minden lehetséges elemet, és a felsorolt elemek egy részének alkalmazása (a dőlt betükkel szedett almezők) pedig fakultatív. A szabályzat ennek megfelelően rugalmasan alkalmazandó, viszont az azzal ellentmondásban álló megoldások alkalmazása tilos. A tárgyszavazás során a szabályzat mellett kötelezö figyelembe venni az adatbázisban található korábbi megoldásokat, és - természetesen - az adott kiadvány tartalmát.." ${ }^{\prime 6}$ Mindez sugallja, hogy az általánosan közös, valamint a szakterületek saját szabályzatrészletei mellett marad még mozgástere a feldolgozónak, valamint a tárgyszóláncokban használható fogalmak köre sem kötött.

A szabályzat az alapelvek meghatározásával indít. Többek között kimondja, hogy 1. az egyetem könyvtáraiban a szépirodalom kivételével a szabályzat szerinti tartalmi feltárás kötelező; 2. a megfelelő tárgyszólánc megalkotásánál elsődlegesen a dokumentum tartalmát, a szabályzat vonatkozó részét, illetve az integrált könyvtári rendszerben található hasonló témakörü kiadványok megoldá-

${ }^{5}$ Aszalós Károly et al.: ELTE EKSZ tartalmi feltárás (tárgyszavazás) szabályzata. 2015. http://hdl.handle.net/10831/33295 (2020. szeptember 23.)

${ }^{6}$ Aszalós Károly et al.: i.m. 11. p. 
sait kell figyelembe venni; 3. a tartalmi feltárás nyelve magyar, de párhuzamos használatként más nyelvek alkalmazása is megengedett; 4. analitikus tartalmi feltárást csak analitikus rekordokban szabad alkalmazni. Elméleti elvei között négy témakör szerepel: 1 . az egységesség, amelynek a szóhasználatban, a formai megoldásokban, a tárgyszóláncok képzésében érvényesülnie kell; 2. az értelmezhetőség és egyértelmüség, amely szerint egy kifejezés egy fogalomnak felelhet csak meg, több lehetőség esetén el kell határolni és meg kell különböztetni őket; 3. az egyszerüség, amely szerint minél kézenfekvőbb legyen a tárgyszólánc megfogalmazása, valamint a szóhasználatban a kategóriajellegnek kell dominálnia; és végül a 4. a specifikusság, miszerint a tartalom kifejezése elsősorban a dokumentum konkrét tárgyához kapcsolódik. ${ }^{7}$

Az EKSz katalogizálói a MARC21 szabványt követik, és ennek megfelelően a tartalmi feltárásban a következő mezők használatosak:

\begin{tabular}{|l|l|}
\hline \multicolumn{1}{|c|}{ MARC hívójel } & \multicolumn{1}{|c|}{ Megfelelö } \\
\hline 600 & személynév \\
\hline 610 & testületi név \\
\hline 611 & rendezvénynév \\
\hline 630 & egységesített cím \\
\hline 650 & tematikus tárgyszó (vagy tárgyszólánc) \\
\hline 651 & földrajzi név \\
\hline 653 & szabad tárgyszó: formai elemek \\
\hline
\end{tabular}

2. táblázat. A tárgyszavazásra alkalmazható mezők

A szabályzat kitér az egyes MARC-mezőkben használható indikátorokra és almezőkre is, vagyis az elméleti-fogalmi bevezetôn és az útmutató gerincét alkotó szakterületi szabályzatleírásokon túl e témakörben is igyekszik naprakész és teljes körü segítséget nyújtani.

Az egyes tudományterületek szakozási szabályzata minden esetben a szakterület szerint illetékes kari könyvtáros(ok) bevonásával, nem ritkán az általuk készített munkaanyagra épülve készült el. A TAMB munkamódszere szerint egyegy elkészült szabályzatrészt mindig véleményezhetett az EKSZ-tagkönyvtárak könyvtárosainak közössége, majd e szabad hozzászólási, javaslattételi idő lejárta után bocsátották csak szavazásra. A szabályzat mostanra teljessé vált, és a következő témakörök szakozási módját fedi le:

\footnotetext{
${ }^{7}$ Aszalós Károly et al.: i.m. 11-12. p.
} 


\section{Részletes szabályok}
Általános múvek (E.)
E. I. Írás
E. II. Bibliográfiák, katalógusok
E. II.1. Bibliográfiák
E. II.2. Katalógusok
E. III. Kéziratok
E. IV. Lexikonok, enciklopédiák
E. V. Periodika
E. VI. Könyvtár

Filozófia (Fil.)

Fil. I. Sémák

\section{Pszichológia (Pszi.)}

Pszi. I. Általános megjegyzések

Pszi. II. Sémák

Pszi. III. Pszichológiai irányzatok, iskolák

Pszi. IV. Kísérleti pszichológia

\section{Vallás (Vall.)}

Vall. I. Sémák

Vall. II. Szerzetesrendek

Vall. III. Biblia

\section{Statisztika (Stat.)}

Stat. I. Sémák

Stat. II. Ágazati statisztikák

\section{Szociológia (Szoc.)}

Szoc. I. Sémák

Szoc. II. Elsődleges és másodlagos irodalom

Szoc. III. Egyéb szabályok

Szoc. III.1. Módszertani irodalom

Szoc. III.2. Ágazati szociológia

Politika (Pol.)

Pol. I. Általános megjegyzések
Pol. II. Politikatörténet

Pol. III. Sémák

Pol. IV. Másodlagos irodalom

Pol. V. A „politikai” kezdetű jelzős szerkezetek

Pol. VI. Politikai pártokra vonatkozó irodalom

Pol. VII. Konfliktusok

\section{Jogtudomány (Jog)}

Jog I. A főtárgyszó

Jog II. „Jog” utótagú összetett szavak Jog III. Sémák

Jog III.1. Jogtudományi müvek

Jog III.2. Tételes jogot tárgyaló müvek

Jog IV. Jogösszehasonlítás

Jog V. Fogalomtárak, szótárak

Jog VI. Jogforrások, jogforrásgyüjtemények

Jog VI.1. Nemzeti jogforrás

Jog VI.1.1. Egyedi jogforrás

Jog VI.1.2. Jogszabálygyüjtemények

Jog VI.2. Nemzetközi jogi forrás, nemzetközi jogi dokumentum

Jog VII. Döntvénytár

Jog VIII. Kommentár, jogmagyarázat Jog VIII.1. A 630-as mező használata Jog VIII.2. Címek helyesírása Jog IX. Jogtörténet Jog IX.1. 'Történeti' jogok Jog IX.1.3. Ókori jogok

Jog IX.1.4. Középkori népjogok és társadalmi, területi szokásjogok Jog IX.2. Történeti jogok jogforrásai Jog IX.3. Római jog Jog IX.4. Újkori történeti jogforrás Jog IX.5. A jogrendszer és jogi rendszer részleges történeti tárgyalása 


\section{Hadtörténet (Had.)}

Had. I. Sémák

Had. II. A "hadtörténet” szó használata

Had. III. Egyéb katonasággal kapcsolatos témák

Had. IV. Csaták

Had. V. Világháború

\section{Pedagógia (Ped.)}

Ped. I. Séma

Ped. II. Általános megjegyzések

Ped. III. Tantárgyak

Ped. III.1. Általános képzés

Ped. III.2. Szakmai képzés

Ped. III.3. Nyelvkönyvek

Ped. IV. Oktatási intézmények

Ped. V. Egyéb szabályok

Ped. V.1. Alternatív nevelési programok

Ped. V.2. Tesztek elnevezései

Ped. V.3. Etnikai és más csoportok nevelése

Ped. VI. Gyógypedagógia

\section{Néprajz (Nép.)}

Nép. I. Sémák

Nép. II. Földrajzi név és etnikai elnevezések

Nép. III. Népköltészet

\section{Természettudományok és mate- matika (Ter.)}

Ter. I. Jelzős szerkezetek

Ter. II. Tudományág alkalmazása

Ter. III. Egyes tudományágak történetének kifejezése

Ter. IV. A természettudományok elméletei, tételei
Élő természettudományok (Biol.)

Biol. I. Általános megjegyzések

Biol. II. Növény- és állatrendszertan

Biol. III. Sorrendiség

Orvostudomány (Orv.)

Orv. I. Sémák

Orv. II. Betegség kifejezése összetett szóval

\section{Múvészetek (Múv.)}

Műv. I. Általános megjegyzések

Müv. II. Sémák

Mủv. III. Irányzatok

Mủv. IV. Motívumok

Mủv. V. Múzeumi gyüjtemények

\section{Nyelvészet ( $\mathbf{N y . )}$}

Ny. I. Egyes nyelvek

Ny. I.1. Séma

Ny. I.2. Nyelvtörténeti korszakok

Ny. I.3. Nyelvészet, földrajzi szükítés

Ny. I.4. Nyelv társadalmi szempontú szükítése

Ny. I.5. Több nyelv együttes tárgyalása

Ny. II. Általános nyelvészet

Ny. III. Összehasonlító nyelvészet

Ny. IV. Egyéb szabályok

Ny. IV.1. Szótárak

Ny. IV.2. Nyelvészeti irányzatok

\section{Irodalom (Ir.)}

Ir. I. Szépirodalom

Ir. I.1.1. Szépirodalom és másodlagos irodalom

Ir. I.1.2. Irodalmi müfajok, melyeket szépirodalom esetén is tárgyszavazunk

Ir. I.1.3. Gyüjteményes mủvek, válogatások 
Ir. I.1.4. Egyéb esetek

Ir. II. Másodlagos irodalom

Ir. II.1. Séma

Ir. II.2. A bővített általános séma tipikus esetei

Ir. II.2.1. Müfaji szükítés

Ir. II.2.2. Földrajzi szükítés

Ir. II.3. Nem irodalmi szempontú besorolás

Ir. II.4. Párhuzamos tárgyszólánc esetei

Ir. II.4.1. Irányzatok

Ir. II.4.2. Két vagy több irodalmat együtt tárgyaló művek

Ir. II.4.2.1. Hatás és recepció

Ir. II.4.2.2. Összehasonlító irodalomtörténet vagy irodalomtudomány

Ir. II.4.2.3. Téma és motívum szempontú tárgyalása

Ir. II.5. Egyéb, az alapsémától eltérő esetek és általános megjegyzések

Ir. II.5.1. Világirodalom

Ir. II.5.2. Irodalomtudomány

Ir. II.5.3. Irodalmi... kezdetủ kifejezések

Ir. II.5.4. Müfordítás, fordítás

Földrajz (Föld.)

Föld. I. Földrajzi nevekre vonatkozó szabályok
Föld. II. Mezőre és almezőre vonatkozó általános szabályok

Föld. III. A 651-es mező használatának esetei

Föld. III.1. A földrajzi meghatározottság jelzése

Föld. III.2. A 651-es mező eltérő használata

Föld. III.2.1. Kisebb jelentőségü helységek

Föld. III.2.2. Nagyobb jelentőségü helységek

Föld. III.2.3. Kiemelt jelentőségü helységek

\section{Történelem (Tör.)}

Tör. I. Történelem tematika

Tör. II. Sémák

Tör. III. Specifikus szabályok

Tör. III.1. Történelmi földrajzi elnevezések

Tör. III.2. Időmegjelölés alkalmazási szabályai

Tör. III.3. Egyéb szabályok

Tör. III.3.1. Történelmi események

Tör. III.3.2. Történelmi korszakok

Tör. III.3.3. Történeti forrás

Tör. III.4. Történelem kiegészítés

A szabályzatot mellékletként kiegészíti egy szinonimalista és egy fogalomtár. Előbbi párokba állítva tartalmazza a használatos és a kerülendő (az integrált könyvtári rendszerben utalóval jelzett) fogalmakat, míg utóbbi fogódzót ad az egymáshoz közel álló fogalmak értelmezéséhez, hogy használatuk egységesen, a megadott meghatározásoknak megfelelöen elkülönülhessen.

Ha tartalmi feltárásról van szó, nem mehetünk el a nem természetes nyelvi feltárás mellett sem. Ez az ELTE könyvtári hálózatában hagyományosan az ETO, amit azonban az idő előrehaladtával egyre kevesebb könyvtárban alkalmaznak. A szabály és hagyomány szerint az Egyetemi Könyvtárban fel- 
dolgozott modern folyóirat- és könyvállomány, valamint a kisnyomtatványok ETO-zása kötelező, EKSz-szinten pedig nem szabad kitörölni, ha betöltéskor valamely más könyvtár rekordjából bekerül, vagy ha már más ok miatt már szerepel egy módosítandó rekordban.

\section{A Google árnyéka}

A 2010-es évek végére az ELTE könyvtárainak java része betagozódott az integrált könyvtári rendszerbe, vagyis a korábbi leírások migrálásán kívül az új rekordok leírása már itt történik, elvártan az időközben elfogadott formai ${ }^{8}$ és tartalmi szabályzat szerint. E szabályzatok megalkotása és bevezettetése komoly szakmai lépés volt az egységes dokumentumfeltárás felé, azonban néhány makacs problémával változatlanul meg kell küzdenünk.

Az adatbázisban jelenleg több mint 300000 különböző tárgyszólánc található. Ez az össz rekordszámhoz viszonyítva nem adja ki a 3,0-s átlagot: vagyis egy tárgyszólánchoz átlagosan kevesebb, mint 3 leírás (könyv, folyóirat, kisnyomtatvány stb.) tartozik. Ennek több oka van: részben néhány könyvtárban még mindig zajlik a migrálás utáni rekordjavítás, részben a használandó kifejezések relatív szabályozatlansága tág teret enged az egyénre jellemző szókincs használatának (és adott esetekben a szinonimalista mellőzésének). Ám a legtöbb új rekord az időbeli és formai elemek különbözősége miatt készül.

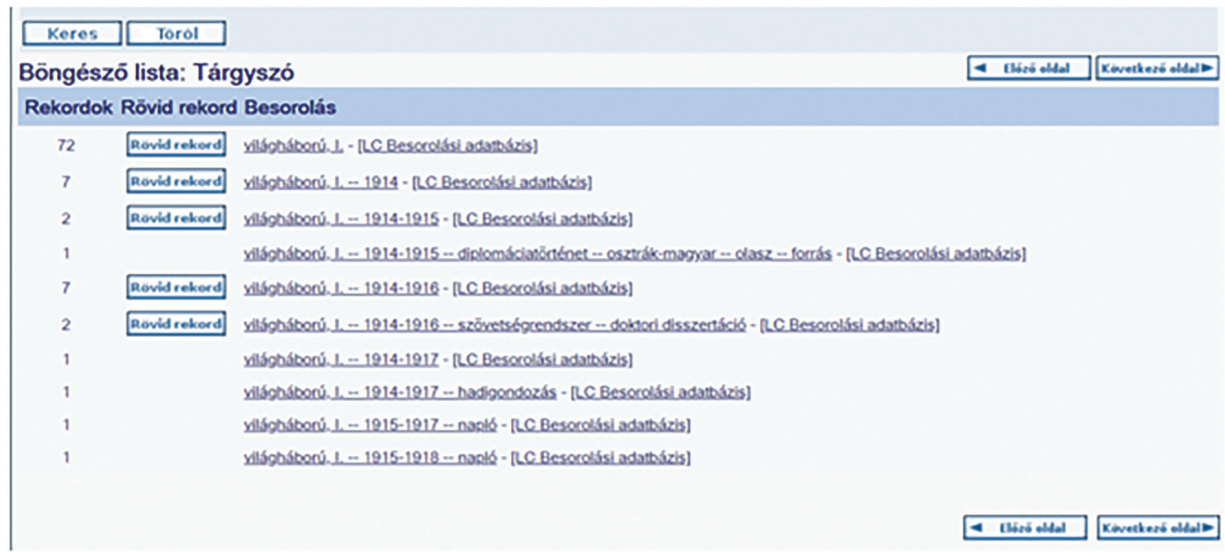

1. ábra. A tárgyszóláncok aprózódása

A tárgyszóláncos feldolgozási módszerben egészen pontosan tüntetjük fel az időbeli és formai elemeket, így fejezve ki teljesen precízen a dokumentum tar-

\footnotetext{
${ }^{8}$ Mező Csaba - Sándor Judit - Székelyné Török Tünde: Katalogizálási Segédlet: Aleph integrált könyvtári rendszer. Budapest, ELTE Egyetemi Könyvtár. 2011.
} 
talmát. Az ebből fakadó kényszerủ aprózódás a böngésző szempontú keresés fontosságát helyezi előtérbe.

Ezen a ponton elérkezünk a visszakeresés kérdésköréhez: vajon ezen aprózódás ellenére is megtalálja az olvasó a keresett témájú dokumentumokat? Ennek kiderítésére - a tájékoztatásban részt vevő kollégák tapasztalatai mellett lekérdezéseket végeztünk az OPAC-on, megnéztük, az olvasók milyen kereséseket indítanak a tárgyszó mezőkben. Az eredményről a „Google árnyék”-ára asszociáltunk: jellemzően egy-egy, a tartalmat vagy témakört hol köznyelvi, hol naprakészen tudományos nyelvezettel lefedő szóra kerestek rá. A többmezős keresés ritka volt, tehát a tárgyszóláncos feltárás előnye - az alapos, mély tartalmi feltárás mellett az idő- és helybeli, valamint a formai meghatározottság - az első találati halmazban kevéssé érvényesülhetett. A magyar nyelvüek mellett találtunk idegen nyelvü, elsősorban angol lekérdezéseket is, ami megerősítést adott ahhoz, hogy az angol nyelvü feltárással is komolyabban kell foglalkozni. (Jelenleg az idegen nyelvü könyvek esetében kötelező a magyar nyelvü tartalmi feltárás, de emellett megengedett a dokumentum nyelve szerinti is. Amennyiben ez az angol, akkor viszont a Library of Congress tárgyszóláncainak használata a kötelezö.) Az ELTE Intézményfejlesztési Tervében ${ }^{9}$ is nagy hangsúlyt kap a nemzetköziesítés, a nyitás, amelyet az oktatást és kutatást szolgáló dokumentumok következetes, angol nyelvü visszakereshetővé tételével is támogathatunk, legalább az idegen nyelvüeknél.

Az OPAC-on indított olvasói keresések időszakos lekérdezéseinek tanulságain felül a mindennapi munka során is megfogalmazódnak bennünk kérdések. Az egyik ilyen a szépirodalom tárgyszavazása. A szépirodalmi mủvek jelenleg csak ETO-számot kapnak, de ennek ismerete, használata nem várható el az olvasóktól. Ebből következik, hogy „,norvég regény”-t, „,skandináv krimi”-t, vagy éppen egy „magyar verseskötet”-et reálisan az online katalógusunkban csak cím vagy szerző alapján kereshet a használó, az OPAC egy nagy találati halmazában böngészgetve nem. Emiatt terveink között szerepel, hogy az ETO-számokból géppel tárgyszóláncokat generáljunk (pl. 894.511-31-ből 65004 \$a magyar irodalom \$x regény), s azokat a dokumentumok leírásában elhelyezve segítsük az ilyen irányú kereséseket is.

A 300 000-nél is több különbözö tárgyszólánccal, a 3,0-t sem elérő átlagolt kapcsolódó rekordszámmal sem lehetünk elégedettek. Az életbe lépett tartalmi feltáró szabályzat szintaktikai változásai, valamint a folyamatosan épülő szinonimalista a tárgyszóláncok ütemezett javítását kívánja, kívánná meg. Ez azonban a napi feldolgozói munkán felüli plusz, melyre nagyon kevés EKSztagkönyvtárban, és akkor is jellemzően csak időszakosan (például a nyári zárvatartás alatt) van kapacitás. A korrektezés hatását és kézzelfogható hasznát

\footnotetext{
${ }^{9}$ https://www.elte.hu/dokumentumok/ift (2020. július 15.)
} 
viszont sajnos gyengíti, hogy tapasztalataink szerint a tömegesen kijavított tárgyszóláncok egy kis idő múlva ismételten felbukkannak az adatbázisban. Nyári felmérésünk szerint tartalmi feltárást jelenleg 39 fő végez az ELTE könyvtári hálózatában, tehát a szabályok betartásán és betartatásán felül ennyi, egymástól gyakran fizikailag is távol lévő ember gondolkodásmódjának és szóhasználatának teljes összehangolására lenne szükség. Emellett a dolgunk az is nehezíti, hogy az Aleph informatikai jellemzői nem teszik lehetővé, a tárgyszavakat vagy tárgyszóláncokat csak egy kötött listából, háttértáblából lehessen kiválasztani.

Végezetül mostanra az a kérdéskör is egyre élesebben körvonalazódik, hogy milyen hatékonysággal tudunk alkalmazkodni a közös katalógusokhoz, kapcsolódni más rendszerekhez. Ez jelenthet ELTE-n belüli és kívüli adatbázisokat, könyvtári katalógusokat, közös keresőket is. Az integrált könyvtári rendszer mellett más, könyvtárosok által épített adatbázisokba is kerül(het)nek be tartalmi szempontú visszakeresést segítő kifejezések: az egyik ilyen az egyetem intézményi repozitóriuma, az ELTE Digitális Intézményi Tudástár (EDIT, http://edit. elte.hu). A repozitórium felépítése már önmagában hordoz bizonyos formai és tartalmi kategorizálást, részben szervezeti hierarchia, részben dokumentumtípus szerint. A feltöltött, egyetemen készült vagy itt lévő tartalmak (pdf-ek, képfájlok, videofelvételek stb.) leírásában magyar és/vagy idegen nyelvủ absztrakt, illetve kulcsszavak feltüntetésére van lehetőség, de meglétük (és párhuzamos fizikai tárolás esetén az integrált könyvtári rendszerbeli leírással egyezésük) nagyban függ a tétel repozitóriumba kerülésének módjától, a kézi feltöltéstöl vagy áttöltéstől, és idejétől. A közös katalógusok, források irányában nagy várakozással tekintünk a Nemzeti Névtér (http://abcd.hu) lehetőségei felé, ami jelenleg várható indulási állapotában elsősorban a tárgyi melléktételek, a személynevek, a földrajzi nevek és a testületi nevek közös(ebb), egységesebb nyilvántartásában segíthet minket.

\section{Utak és irányok}

A fentebb felsorolt, részben belső, részben külső körülmények alakította rendszerben meg kell határoznunk, mik a jó gyakorlatok, mik azok, amin változtatnunk kell, és mindebböl reálisan mit tudunk megvalósítani.

A szervezeti széttagoltságon nem tudunk változtatni, de a tartalmi feltárással foglalkozó könyvtárosok szorosabb együttmüködésével elő tudjuk segíteni a közös munkát. Ezt az évente kétszer tartott tanfolyamok, továbbá az egyéni megbeszélésen alapuló konzultációs lehetőségek is mindenképpen segítik. El kell érni, hogy az adott tartalmat ugyanabban a mélységben és ugyanazzal a fogalommal írja le mindenki - ami ráadásul egyezzen meg a tudományterület müvelöinek fogalomhasználatával. Egy nagy tudományegyetemen a szakszókincs változását első kézből érzékeljük, amit a katalógusunknak rugalmasan követnie kellene. Mindezek optimálisan egy terminuslista, tezaurusz használatát feltételezik: egy 
olyan szójegyzékét, amely meghatározza, mely kifejezéseket lehet használni a tartalmi feltárás során (és amelyek ideális esetben az ETO-számot és az angol megfelelöt is tartalmazzák). Középtávú terveink között ennek bevezetése is szerepel. Ha ez megtörténne, az olvasók könnyebben megtalálhatnák, hogy az adott tartalmat mely fogalommal fedjük le, továbbá a feldolgozók egységesebb fogalmi keretben dolgozhatnának.

Addig is, amíg ez elkészül, tehetünk két lépést a tárgyszóláncok széttagoltsága ellen: egységesíthetjük az időmegjelöléseket és leválaszthatjuk a láncok végéről a formai elemeket. Az időre vonatkozó egészen pontos évmegjelöléseket (pl.: \$a világháború, I. \$y 1914; \$a világháború, I. \$y 1914-1915; \$a világháború, I. \$y 1914-1916; \$a világháború, I. \$y 1914-1917 stb.) a szabályzat szerint már most is ki lehetne váltani korszakokkal (\$a világháború, I. \$y 19141918), de ezen a téren a szokások és hagyományok még erősebbek. Ami a formai elemeket illeti, a MARC21 megengedi, hogy a 653-as mezőben kerüljenek feltüntetésre a „doktori disszertáció”, ,felsőoktatási tankönyv”, „tanulmányok” stb. típusú elemek, melyek a szüken vett tartalomhoz nem, csak a kifejezési, megjelenési forma azonosításához járulnak hozzá. Külön mezőben kezelésükkel nagy mennyiségủ tárgyszólánc összevonható lenne.

A láthatóságot, illetve a szemantikus weben megjelenést, továbbá a más katalógusokkal, adatbázisokkal kialakítandó kapcsolatot az egyedi azonosítók használata segíti elö. Ezek a világszinten elfogadott egyedi azonosítók a tartalmi feltárás területén elsősorban a tárgyi melléktételeknél hozhatnak hasznot: a személynevekhez a Virtual International Authority File-t (VIAF, http://viaf. org), a földrajzi nevekhez a GeoNames-t (https://www.geonames.org) tervezzük rögzíteni. Meglétük az azonos alakú személy- és földrajzi nevek esetében is egyértelmüvé teszi az azonosítást, mellyel reményeink szerint megkönnyítik majd csatlakozásunkat a Nemzeti Névtérhez is.

A feldolgozási gyakorlatunkat érintő fejlesztések mellett a könyvtári katalógusunk használatát is segíthetjük. Nagy hangsúlyt helyezünk a felhasználóképzésekre: amennyiben a katalógushasználat bemutatása kitér a tartalmi viszszakeresésre, különösen a böngésző keresés fontosságára, az olvasók sokkal könnyebben eligazodhatnak a rekordjaink között.

\section{Rezümé}

Az Eötvös Loránd Tudományegyetemen 2009-ben jött létre az Egyetemi Könyvtári Szolgálat, majd a tartalmi feldolgozás egységesítését, a közös katalogizálás megszervezését és koordinálását segítendő 2012-ben megkezdte müködését a Tartalmi Feltárás Almunkabizottság. A tanulmány bemutatja a közös munka keretében megvalósult eredményeket, kitér a jelenlegi állapotra és felvázolja a jövőbeli lehetőségeket. 


\section{Subject Indexing \\ in the University Library Service of Eötvös Loránd University}

The University Library Service was established in 2009 at the Eötvös Loránd University. In 2012, the Committee of Subject Indexing began its mission to systematise and regulate the content processing and subject headings and unify the system of cataloguing amongst the faculties of the university. This study presents the achievements of this committee, and details its current statis and its proposals for the future .

SZABÓ PANNA osztályvezető-helyettes ELTE Eötvös Loránd Tudományegyetem Egyetemi Könyvtár és Levéltár ORCID: 0000-0002-9540-6374

SOT FERENC könyvtáros ELTE Eötvös Loránd Tudományegyetem Bárczi Gusztáv Gyógypedagógiai Kar Könyvtár és Gyógypedagógia-történeti Gyüjtemény 